\title{
ANALISIS PERCAKAPAN BAHASA SASAK DALAM PERSPEKTIF GENDER: SEBUAH KAJIAN WACANA KRITIS
}

\section{(THE ANALYSIS OF SASAK LANGUAGE FROM THE GENDER PERSPECTIVE: A CRITICAL DISCOURSE ANALYSIS)}

\author{
Irma Setiawan
}

\author{
Universitas Mataram \\ Jalan Majapahit Nomor 62 Komplek Kampus FKIP UNRAM \\ Gedung A Lantai 1 Mataram, NTB, Indonesia 83125 \\ Pos-el: Irmasetiawan9@gmail.com
}

Diterima: 25 September 2013; Direvisi: 30 Oktober 2013; Disetujui: 1 November 2013

\begin{abstract}
Conversations are often used as medium to transfer ideas of speakers. Therefore, the purpose of this research is to describe the role of Sasak men and women in lexical choice, interactional controls, syntactic structures, and metaphors usage in Sasak conversational language. The theory used is Norman Fairclough discourse critical model added by Teun A. Van Dijk's theory. The Data collected using observational methods, interviews, basic techniques and its derivatives, methods of observation, and documentation methods. Data sources were obtained from young men and women communicating Sasaknese. The data were analyzed by using qualitative descriptive method aimed to make systematic description, categorization, and patterning. The data were presented formally and informally. The research finally produced motives reality or ideological stance of communicators over roles of men and women in the Sasak gender perspective which often lead to physical and psychic intersection, such as sexual harassment, domestic violence, and even to the culture of divorce and remarriage.
\end{abstract}

Keywords: conversation, Sasak language, gender perfective, Norman Fairclough discourse critical model

\begin{abstract}
Abstrak
Percakapan kerap digunakan sebagai media mentransfer ideologi para penutur. Oleh sebab itu, tujuan penelitian ini untuk: mendeskripsikan representasi peran laki-laki atau perempuan Sasak dalam pilihan kosakata, dalam melakukan kendali interaksional, dalam struktur sintaksis, dan dalam pemakaian metafora dengan percakapan bahasa Sasak. Teori yang dipergunakan adalah teori wacana kritis model Norman Fairclough dan dilengkapi oleh teori Teun A. Van Dijk. Pengumpulan dilakukan dengan metode simak dan cakap (wawancara) serta teknik dasar dan turunannya, metode observasi, dan metode dokumentasi. Sumber data diperoleh dari para pemuda dan pemudi Sasak yang sedang berkomunikasi. Data yang terkumpul dianalisis dengan metode deskriptif kualitatif yang bertujuan untuk membuat deskripsi secara sistematis, kategorisasi, dan pemolaan. Data disajikan secara formal dan informal. Pada akhirnya, penelitian ini menghasilkan realita motif atau ideologi sikap komunikator yang memihak peran laki-laki atau perempuan Sasak dalam perspektif gender, yang kerap menimbulkan persinggungan fisik-psikis, seperti; pelecehan seksual, KDRT, dan bahkan dalam budaya kawin cerai.
\end{abstract}

Kata kunci: percakapan, bahasa Sasak, perspektif gender, wacana kritis model Norman Fairclough

\section{Pendahuluan}

Tuturan Sasak sangat identik dengan pengastaan sosial para penuturnya di masyarakat. Penutur yang berstatus sosial rendah mempergunakan ragam halus untuk berkomukasi dengan penutur yang berstatus sosial tinggi. Sebaliknya ragam kasar kerap dipergunakan penutur bersatus sosial tinggi terhadap penutur berstatus sosial rendah. Akibatnya, dalam interaksi terjadi ketidakberimbangan nilai tuturan. Hal ini berdampak pada terbentuknya kelas tinggi 
dan rendah di masyarakat, seperti halnya pada sebutan status sosial laki-laki dengan istilah raden [raden], lalu [lalu] dan baiq [bai?], dende [denda] dan lale [lala] sebagai sebutan status sosial perempuan. Di samping itu, penggunaan ragam halus dan kasar, seperti; side-kamu 'Anda/kamu', tiang-aku 'aku/saya', dan sebagainya berpengaruh pada terbentuknya pola superior dan inferior dalam masyarakat Sasak.

Penyebutan status sosial yang beragam di masyarakat Sasak, juga terjadi pada interaksi sosial antarperempuan dan laki-laki. Keduanya kerap didapati berkomukasi dengan ragam halus dan kasar. Pihak laki-laki selalu mendominasi kedua bentuk ragam bahasa, sedangkan pihak perempuan sebagai sosok yang direpresentasikan lemah dalam percakapan hanya berkutat pada ragam halus. Lantas kondisi ini mempertegas karakter masyarakat Sasak yang sangat menjunjung tinggi faham patrilineal yang memosisikan pihak laki-laki sebagai pengayom, pengarah, dan penanggung jawab dalam kehidupan, sebaliknya perempuan sebagai sosok yang patuh dan taat. Tentu kehidupan seperti ini, dianggap kerap menimbulkan kurangnya akses kaum perempuan di sektor publik, yang pada akhirnya memicu persinggungan fisik dan psikis, sehingga memunculkan bibit-bibit konflik antargender.

Lebih dari itu, terbentuknya pola hierarki dalam bahasa Sasak, tidak jarang berakibat terjadinya perubahan arah. Banyak di antara penutur yang tuturannya, justru memuat motif/ideologi terselubung untuk memperdaya lawan bicara, melegitimasi pemahaman, menekan, melawan, dan memperluas pengaruh sosial dalam masyarakat. Pola pikir masyarakat Sasak yang menganggap laki-laki sebagai sosok yang lebih kuat, potensial, dan produktif dalam bekerja, sedangkan pihak perempuan dinilai kurang leluasa karena terbentur oleh kodrat sebagai pihak yang menyusui, hamil, dan melahirkan telah menghambat produktifitas perempuan dalam pergaulan. Akibatnya, perempuan menjadi pihak yang termarginalkan dari akses publik dan kerap mendapatkan perlakuan kurang layak, seperti; Kekerasan Dalam Rumah Tangga (KDRT), pelecehan seksual, perceraian, dan bahkan pembunuhan bermotif asmara.

Berdasarkan data Komnas Perlindungan Perempuan (2012:2) angka kekerasan terhadap perempuan dengan berbagai motif dan tindakan pada tahun 2010 di Indonesia mencapai 105.000 kasus. Sedangkan itu, untuk Pulau Lombok sendiri, data RS Bhayangkara Polda NTB angka kekerasan terhadap perempuan, berupa tindakan fisik paling mendominasi dengan angka 91,97\%, dengan perhitungan tidak semua kasus tercatat secara akurat dikarenakan pelapor tidak berani atau takut melapor.

Berdasarkan uraian di atas, perlu kiranya suatu upaya tanggap dini potensi konflik yang dapat ditimbulkan dari persinggungan dalam percakapan. Sehingga kajian penelitian terhadap bahasa tutur Sasak hanya difokuskan pada pendeskripsian peran sosial perempuan dan laki-laki Sasak dalam pilihan kosakata, kendali interaksional, struktur sintaksis, dan pemakaian metafora dalam tuturan. Sehingga pada akhirnya, ideologi terselubung para penutur dalam interaksi membentuk stereotip gender dapat diminimalkan guna mencegah timbulnya bibit-bibit konflik gender.

\section{Kerangka Teori}

Percakapan merupakan bentuk aktualisasi pemikiran penutur dalam upaya pemenuhan segala kebutuhan hidup si penutur itu sendiri. Santoso (2009:1-2) menerangkan laki-laki dan perempuan memiliki identitas percakapan sendiri, perempuan lebih sering dan cenderung menggunakan gaya tutur kooperatif dan 
bertahan, sebaliknya laki-laki lebih cenderung menggunakan gaya tutur kompetitif dan menyerang.

Gender merupakan konsep pemisahan yang didasari pada perbedaan peran di masyarakat tertentu. Gender bukanlah jenis kelamin, melainkan gender sebagai pembeda peran perempuan terhadap laki-laki. Hal ini ditegaskan Nugroho (2008:31) bahwa gender sebagai pembeda yang didasarkan peran sosial di masyarakat. Sehingga arah konsep gender lebih kepada fungsi/peran dan kedudukan perempuan atau laki-laki dalam interaksi sosial. Di samping itu, Kadarusman (2005:21) menegaskan gender sebagai suatu konsep kultural yang membedakan antara laki-laki dan perempuan dipandang dari segi sosial budaya yang dapat berubah sesuai dengan perkembangan zaman. Artinya, konsep gender sebagai representasi budaya suatu masyarakat cenderung berubah-ubah sesuai dengan perkembangan zaman dan kontrak sosial di masyarakat itu sendiri.

Analisis wacana kritis (Darma, 2009:49) merupakan sebuah upaya atau proses (penguraian) untuk memberi penjelasan dari sebuah teks (realita sosial) yang mau atau sedang dikaji oleh seseorang atau kelompok dominan yang kecenderungannya mempunyai tujuan tertentu untuk memproleh apa yang diinginkan, artinya dalam sebuah konteks harus disadari akan adanya kepentingan. Sejalan dengan itu, teori penganalisisan yang dipergunakan dalam menelaah setiap tuturan berperspektif gender adalah teori analisis wacana kritis Norman Fairclough (1989, 1998, dan 2006) yang mengulas kosakata, kendali interaksional, pemakaian metafora, dan dikolaborasikan dengan teori dan struktur sintaksis oleh Van Dijk (2004), meskipun Jorgensen dan Phillips (2007:122) telah menegaskan sederet konsep Fairclough yang berbeda yang saling berkaitan satu sama lain dalam model tiga dimensi yang kompleks, selanjutnya makna konsepkonsep tersebut beragam karena kerangka analisis yang ditawarkan senantiasa mengalami perkembangan, artinya konsep kajian terhadap teks lisan atau tulis tidak menutup kemungkinan mengalami perkembangan.

\section{Metode Penelitian}

Penelitian ini mempergunakan pendekatan Critical Linguistics yang senantiasa melihat bagaimana gramatika suatu bahasa atau ungkapan membawa posisi dan makna ideologi tertentu. Dengan kata lain, aspek ideologi itu diamati dengan melihat pilihan bahasa dan struktur tata bahasa yang dipakai. Ideologi dalam taraf yang umum menunjukkan bagaimana suatu kelompok berusaha memenangkan dukungan publik, dan bagaimana kelompok lain dimarjinalkan lewat pemakaian bahasa dan struktur gramatika tertentu (Eriyanto, 2009:15,133). Sedangkan makna dalam tuturan suatu produksi sosial, suatu praktik, artinya pemaknaan suatu kata-kata hanya digunakan untuk menentukan realitas dan bukan sebaliknya.

Populasi penelitian ini dilakukan di wilayah Lombok Timur dengan dialek ngeno-ngene dan sampel di daerah Selong dan Pancor dengan menggunakan yang kriteria informan (Mahsun, 2005:141) seperti, 1) berjenis kelamin perempuan atau laki-laki, 2) berstatus sosial menengah dengan harapan tidak terlalu tinggi mobilitasnya, 3) memiliki kebanggaan terhadap isoleknya, 4) dapat berbahasa Indonesia, dan 5) sehat jasmani dan rohani. Data informan (terlampir) yang menjadi sampel dan dijadikan objek atau data pengkajian, didapat dengan cara acak (random sampling) dengan tetap memperhatikan kriteria informan yang telah ditetapkan sebelumnya. Metode dan teknik analisis data dilakukan dengan (Mahsun, 2007:92) metodek simak (teknik simak libat 
cakap dan teknik bebas libat cakap), metode cakap (teknik pancing dan teknik lanjutan cakap semuka) dan dokumentasi untuk memperjelas keakuratan data itu sendiri.

Metode analisis data dilakukan dengan metode deskripsi dan dianalisis dengan teknik kualitatif untuk melakukan kategorisasi dan pemolaan ujaran yang menstereotipkan perempuan dan laki-laki dalam percakapan para informan. Prosedur penganalisisan dilakukan dengan menggunakan pendekatan induktif yakni data yang didapat di lapangan dianalisis dengan pemikiran yang didasarkan atas hal yang spesifik kemudian ditarik kesimpulan atas hal yang bersifat general. Dengan demikian, data yang didapat dapat mewakili keseluruhan objek penelitian.

\section{Pembahasan}

Representasi gender dalam strata sosial masyarakat Sasak ditunjukkan melalui beragam tuturan. Ragam kosakata dalam tuturan yang dipergunakan para penutur, memuat berbagai bentuk atributif yang memisahkan peran sosial perempuan dan laki-laki di masyarakat. Seperti halnya yang dijelaskan sebelumnya oleh Santoso (2009:1-2), perempuan dan laki-laki memiliki identitas percakapan sendiri, perempuan lebih sering dan cenderung menggunakan gaya tutur kooperatif, sebaliknya laki-laki lebih cenderung menggunakan gaya tutur kompetitif. Oleh karena itu, fenomena ini dapat dicermati melalui beragam tindak tutur yang direkonstruksikan melalui pilihan kosakata, kendali interaksional, struktur sintaksis, dan metafora di bawah ini.

\subsection{Representasi Gender Melalui Pilihan Kosakata}

Penggunaan kosakata tertentu dalam percakapan justru dapat mempertegas status sosial seseorang dalam tuturan. Pihak yang lebih dominan (superior) merasa dirinya sebagai sosok panutan dalam percakapan, sedangkan bagi pihak yang inferior merasa dirinya lemah dan bergantung pada sikap tuturan pihak yang dominan. Keadaan seperti ini, kerap kali dijumpai pada pilihan kosakata percakapan yang melibatkan perempuan dan laki-laki.

Pilihan kosakata laki-laki yang lebih kompetitif dan menekan lawan jenisnya, dianggap dapat merugikan eksistensi peranan perempuan dalam interaksi sosial di masyarakat. Sedangkan itu, perempuan sebagai sosok yang dianggap lebih kooperatif dan tidak berdaya dapat dengan mudah ditekan dan didominasi oleh penutur laki-laki, sehingga kondisi ini telah membatasi askes publik bagi perempuan untuk meningkatkan produktifitasnya.

Ketimpangan peranan sosial dalam tuturan antarkedua pihak, telah direkonstruksikan melalui tuturan yang mengontraskan perempuan dan laki-laki. Pengontrasan gender penutur terbagi dalam dua bentuk, yakni bentuk konstruksi alamiah (natural) dan konstruksi non-alamiah (social). Adapun bentuk pilihan kosakatanya sebagai berikut.

\subsubsection{Pemilihan Kosakata dalam Konstruksi Alamiah}

Pilihan kosakata alamiah merupakan pemilihan kata yang tidak direkonstruksikan secara sosial, melainkan dibentuk atas dasar keyakinan atau kepercayaan yang dianut masyarakat. Masyarakat sangat meyakini dengan menjalankan tuntunan agama berarti telah terhindar dari dosa dan salah. Di sisi lain, tindakan yang tidak diperbolehkan bagi perempuan ataupun laki-laki dianggap sebagai suatu pantangan. Sehingga masyarakat sangat taat dalam menjalani setiap peranan yang melibatkan pihak perempuan dan laki-laki di masyarakat. Adapun percakapan yang merepresentasikan peran atau kedudukan sosial perempuan dan laki-laki dalam percakapan Sasak 
dikontraskan melalui penggunaan kosakata alamiah berikut ini.

L1: Mun aku jeq seangku so iye. [mun aku jeq seay ku so iye] 'Kalau aku, aku ceraikan dia'

L2: Aran ne dengan mame mulan ne demen ngatur. [aran ne dəyan mamo mulan ne demen yatur] 'Namanya saja lakilaki sukanya mengatur'

Penggunaan kata seangku 'aku ceraikan' dan ngatur 'mengatur' oleh penutur laki-laki terhadap penutur perempuan telah menujukkan tatanan status sosial laki-laki Sasak yang sangat kuat dan dominan. Keadaan ini berlaku secara menyeluruh dikarenakan sistem kayakinan atau kepercayaan masyarakat setempat yang tidak memperbolehkan perempuan untuk mengatur berbagai hal dalam kehidupan dan menceraikan pihak laki-laki secara langsung. Namun, bagi pihak laki-laki sangat dilegalkan untuk mengatur pihak perempuan, bahkan dapat menceraikan perempuan secara langsung.

Sedangkan itu, keinferioritasan peran sosial perempuan dalam masyarakat Sasak, telah digambarkan dalam percakapan yang menjelaskan tugas pokok perempuan dalam sektor domestik. Masyarakat berkeyakinan sikap patuh dan taat yang ditunjukkan perempuan sebagai bentuk mengamalkan ajaran keyakinan yang dianutnya. Percakapan yang memperlihatkan keadaaan ini sebagai berikut.

Pihak laki-laki diposisikan sebagai sosok yang berhak menentukan dan mengarahkan perilaku dan tindakan perempuan dalam masyarakat. Sesuai dengan keyakinan kepercayaan yang dianut, laki-laki memosisikan perempuan sebagai sosok yang harus taat pada perintah dan larangan yang ditetapkannya. Sedangkan perempuan tidak memiliki kewenangan untuk bertindak layaknya laki-laki dalam rumah tangga. Sehingga kondisi telah menempatkan perempuan sebagai pihak yang tidak berdaya dan tidak memiliki akses publik untuk bertindak. Keterkekangan perempuan ini dapat dicermati pada kutipan percakapan di bawah ini.

L: Sengaq mun ne wah merariq jari kepale laun leq keluarga ne. [scya? iyz jari kəpalo le? keluarga na] 'karena dia menjadi kepala keluarga nantinya'

Lebih dari itu, kedudukan perempuan yang ditempatkan sebagai pihak yang inferior tidak terlepas atas konstruksi biologis perempuan itu sendiri. Perempuan kerap dianggap kurang memiliki totalitas dalam kinerja karena harus dibatasi dengan kondisi hamil, menyusui, dan menata keuangan dalam rumah tangga. Sedangkan laki-laki tidak terikat dengan kontrak keyakinan itu, laki-laki memiliki akses yang luas untuk mengeksplorasi diri dan bekerja di mana pun untuk kepentingan diri dan keluarganya. Kondisi biologis perempuan yang inferior ditunjukkan melalui percakapan di bawah ini.

P: Bahaya. mun ne sugul kelem, masalah ne ceweq no lemah, gampang te anuq isiq dengan. [bahaya, mun na sugul kalem, masalah no cewe? no lamah, gampay to anu? isi? dəyan] 'bahaya, kalau ke luar malam, masalahnya perempuan lemah, gampang diapa-apakan oleh seseorang'

Penggunaan kosakata kata lemah 'lemah' pada kutipan percakapan yang dituturkan perempuan di atas, memperlihatkan kondisi fisik perempuan yang tidak memungkinkan untuk bertindak layaknya laki-laki. Secara biologis tidak ada yang menampik kalau perempuan memiliki fisik yang lemah dibandingkan fisik laki-laki dan laki-laki sangat dominan secara kodrati dengan keadaan yang lebih kuat dibandingkan perempuan. Keadaan ini secara tidak langsung telah membatasi akses dan intesitas sosial perempuan dalam masyarakat. Perempuan harus menerima keadaan bahwa hidupnya dibatasi oleh keyakinan dan kepercayaan yang dianutnya. 
... Sebuah Kajian Wacana Kritis (Irma Setiawan)

Di samping itu, kondisi biologis yang membenturkan perempuan pada realita sebagai sosok yang lemah, telah memperkuat keyakinan masyarakat untuk melegitimasi pihak laki-laki sebagai sosok yang lebih berwenang dalam masyarakat.

Laki-laki dianggap layak untuk dijadikan panutan karena memiliki segala komponen yang dibutuhkan perempuan. Sedangkan perempuan sebagai pihak yang mencari perlindungan pada laki-laki. Perempuan membutuhkan rasa aman dan nyaman terhadap arogansi pihak lain. Untuk itu, dibutuhkan sikap laki-laki yang konstruktif terhadap kebutuhan perempuan sendiri, karena kedua pihak ini saling berkonstrual dalam membangun tatanan sosial di masyarakat.

\subsubsection{Pemilihan Kosakata dalam Konstruksi Sosial}

Pilihan kosakata sosial merupakan pemilihan kosakata yang didasari atas kontrak sosial di suatu masyarakat. Berbeda dengan kosakata berkonstruksi alamiah, kosakata yang dibentuk dengan perspektif masyarakat diberlakukan atas kesepakatan masyarakat itu sendiri. Setiap masyarakat membentuk pemahaman komunalnya sendiri. Pandangan terhadap pihak perempuan dan laki-laki akan berbeda-beda di setiap masyarakatnya. Misalnya, pada masyarakat perkotaan yang dekat dengan arus globalisasi memiliki perspekstif gender yang berbeda dengan daerah pedesaan yang renggang dengan arus perubahan.

Hal ini berdampak pada pemosisian peran perempuan dan laki-laki dalam suatu masyarakat. Seperti halnya konstruksi gender pada masyarakat Sasak yang direpresentasikan melalui percakapan dapat dicermati pada pilihan kosakata yang mengontraskan peran perempuan dan lakilaki di bawah ini.

\section{L: Demen ne wah te paleng ampoq meq te} tejaq merariq.[damen na wah to palsy ampo? mə? to teja? mərari?] 'suka saja sih, kalau kamu dicuri lalu diajak menikah'

Pilihan kosakata te paleng 'dicuri' dalam konteks perempuan yang dibawa kawin lari oleh laki-laki dalam budaya masyarakat Sasak, sebagai sesuatu yang legal dan lumrah terjadi dalam kehidupan. Sehingga sebagian besar masyarakat Sasak tidak mempersoalkan perihal budaya kaum laki-laki dalam mempersunting perempuan. Fenomena ini juga secara tidak langsung memosisikan perempuan sebagai sosok yang tidak berdaya dan manut terhadap tindakan laki-laki. Sebagai pembanding saja, jika seorang perumpuan bertindak layaknya lakilaki, yang membawa lari laki-laki untuk dipersunting, justru perempuan tersebut dicemohkan oleh masyarakat setempat dan hal ini bukan sesuatu yang dibenarkan secara budaya Sasak. Oleh karena itu, jelas bahwa di samping perempuan di batasi oleh kodratnya sebagai pihak yang patuh dan taat pada laki-laki, juga dibatasi oleh kondisi biologis dan kontrak sosial di masyarakat.

Bentuk kepatuhan perempuan di terhadap laki-laki, secara sadar diakuinya sendiri dalam percakapan di berikut ini.

P: Soal ne no penting. Jemaq merariq ite terus ndeq te tao ngeme, meriap,kelaq,ngerosoq kance minaq reragi. beh ngamuq semamaq te. [soal no no pentin jema?merariq ita terus nde? tao yeme meriap yeroso? kance mina? reragi] 'karena hal itu penting. Nanti kalau sudah menikah terus tidak bisa memasak nasi, mengurus dapur, memasak lauk, mencuci piring, dan membuat bumbu-bumbu, bisa marah suami'

Dipergunakannya pilihan kata ngeme 'memasak nasi', meriap 'mengurus dapur', ngerosoq 'mencuci piring, minaq reragian 'membuat reragian' merupakan bentuk kontrak sosial yang harus dijalani perempuan dalam hidup. Perempuan selalu 
dikonotasikan dengan sosok yang bekerja pada tiga ranah, yaitu dapur, rumah tangga, dan tempat tidur adalah selentingan negatif yang justru sangat merugikan pihak perempuan. Perempuan selayaknya diperlakukan terhormat ditengah kampanye antistereotip gender di masyarakat. Namun, hal-hal seperti ini tidak dapat mengubah paradigma masyarakat untuk tetap menginferioritaskan perempuan.

Ditilik lebih lanjut, keinferioritasan perempuan terhadap dominasi laki-laki juga tidak selamanya berlangsung mulus. Perempuan sebagai sosok yang menyatakan dirinya lemah, tidak berdaya, dan tidak memiliki kemampuan untuk menandingi laki-laki, ternyata melakukan pelanggengan identitas dalam komunitasnya sendiri. Hal ini justru memperparah usaha perempuan dalam menjajarkan diri dengan pihak lakilaki. Perempuan membangun organisasinya dengan ketidaksolidan, sehingga perempuan yang satu dengan perempuan yang lain terkadang terjadi persinggungan psikis dan fisik yang pada akhirnya memperlemah komunitasnya sendiri. Ada beberapa bentuk fenomena yang ditemukan di kalangan masyarakat Sasak yang menunjukkan ketidaksolidan perempuan dalam emansipasi kaumnya adalah sebagai berikut.

a) Perempuan selalu sibuk dengan urusan intern komunalnya, sehingga lupa bahwa emansipasi hak dan kewajibannya ditujukan terhadap pihak laki-laki.

b) Perempuan yang satu dengan yang lainnya kerap tertutup dengan persoalan pribadi sehingga susah diperjuangkan.

c) Pihak perempuan secara sadar telah mengakui dirinya sebagai sosok yang lemah dan harus patuh dengan laki-laki (karena tuntutan ajaran agama) secara tidak langsung telah membuyarkan konsep emansipasi yang diperjuangkannya.

\subsection{Representasi Gender Melalui Kendali Interaksional}

Tindak tutur Sasak dalam interaksi para penuturnya tidak terbebas dari konteks sosial. Tuturan pada dasarnya bukan berada pada tempat atau ruang hampa, melainkan bermetamorfosis dengan mereduksi maknamakna terselubung di balik motif yang terkandung dalam percakapan. Kendali interaksional salah satunya dapat merepresentasikan dominasi suatu individu atau kelompok dalam interaksi. Untuk itu, istilah kendali interaksi sebagai bentuk pengewajantahan superioritas tuturan suatu individu atau kelompok dalam komunalnya.

Terkait dengan itu, kendali interaksional dalam percakapan bahasa Sasak ditunjukan dengan jelas melalui beberapa tindakan. Chaer (2009:50) berpendapat bentuk kendali interaksional dapat berupa penggunaan kata sangkalan seperti; bukan, tidak, tak, tanpa, dan tiada. Dalam pertuturan, jika komunikan mempergunakan pernyataan sangkalan seperti yang disebutkan di atas, dapat dicurigai bahwa orang tersebut memegang kendali untuk menolak atau menerima, untuk didengar atau dituruti, dan sebagainya.

Di samping itu, kendali interaksional dalam percakapan ditunjukan juga melalui bentuk-bentuk tindakan lain, yakni; larangan dan kritikan. Adapun beberapa motif dan pola sangkalan, larangan, dan kritik dalam tuturan Sasak sesuai dengan data yang didapat, sebagai berikut.

a) Untuk menunjukan ketidaksetujuan atau ketidaksukaan terhadap sesuatu hal.

b) Untuk menunjukan jati diri dan eksistensi diri dalam interaksi sosial.

c) Untuk menunjukan bahwa pernyataan dominasi atau superior sebagai penegas diri dalam tuturan.

d) Untuk menunjukan karakter natural dan alamiah (biologis) penutur.

Kendali interaksional dalam tuturan Sasak dirincikan pada ragam percakapan 
berikut. Adapun bentuk-bentuk tindakan ini dapat dicermati pada data berikut.

\subsubsection{Dalam Bentuk Sangkalan}

Sangkalan merupakan suatu tindakan yang berusaha menentang atau menolak dengan tujuan untuk didengar atau dituruti, sehingga lawan bicaranya bersedia mengikutinya. Kata sangkalan biasanya diujarkan pada situasi penutur tidak merespon positif tanggapan atau penyataan lawan bicara, sehingga situasi tuturan menjadi tidak berimbang. Ketidakberimbangan ini juga tersurat jelas dalam ragam percakapan Sasak di bawah ini.

$\mathrm{L}:$ Mun ite no, ndeq ne penting penampilan yang penting hati. [mun its no, ndeq na pentiy penampilan yay pentiy hati] 'kalau saya itu, tidak penting penampilan yang penting penting hati'

P: Laguq keh tetep doang rate-rate ndeq ku percaya leq rayuan ne. [lagu? keh tetep doay rate-rate ndeq $k u$ percaya le? rayuan nə] 'tetapi tetap saja ratarata aku tidak percaya dengan rayuannya'

Percakapan di atas, diperlihatkan bentuk tindakan yang menyatakan sangkalan penutur laki-laki dan perempuan terhadap pernyataan lawan bicaranya. Sangkalan pada pernyataan tersebut berupa penggunaan kata ndek 'tidak' yang menandakan si pembicara laki-laki tidak menilai seseorang atas dasar penampilan, melainkan didasari hati yang tulus, sedangkan pada pernyataan pihak perempuan, sangkalan dimaksudkan sebagai penegeasan terhadap ketidakpercayaannya terhadap rayuan setiap laki-laki. Realitas ini menggambarkan pihak perempuan dan lakilaki sama-sama memiliki kesempatan untuk menentukan sikap atau pernyataan tegas dalam tuturan. Keduanya memiliki kesempatan untuk mengendalikan komunikasi dalam percakapan. Namun, perlu diingat kendali interaksi laki-laki lebih diarahkan pada situasi kompetisi atau usaha untuk menekan. Sedangkan perempuan penyangkalan diperuntukan untuk membela kepentingan dirinya di balik tekanan pihak laki-laki. Sekali lagi bahwa ada benarnya yang dikatakan para ahli, perempuan selalu terkungkung dalam persoalan intern diri dan kelompoknya, sedangkan laki-laki tampil sebagai komunitas yang solid, meskipun secara keseimbangan hormon, laki-laki lebih agresif daripada perempuan.

Aspek lain pada bentuk sangkalan tercermati pada pola sangkalan yang ditunjukan laki-laki bisanya terkait dengan eksistensi atau dominasi diri terhadap lawan bicara, sedangkan bagi pihak perempuan sangkalan sebagai bentuk pembelaan diri terhadap perlakuan laki-laki yang dianggap tidak berterima dengan kehendak si perempuan itu sendiri.

\subsubsection{Dalam Bentuk Larangan}

Larangan merupakan suatu upaya untuk mencegah atau tidak memperbolehkan seseorang atau sekelompok orang untuk bersikap atau bertindak di luar batas kewajaran. Wajar diartikan sebagai sesuatu tindakan yang masih dapat diterima secara logika dan dilegalkan oleh masyarakat setempat. Penggunaan bentuk larangan biasanya berupa kata, seperti: jangan, tidak boleh, tidak usah, dan sebagainya. Pada bentuk ini, percakapan bahasa Sasak ragam bentuk larangan dapat dicermati pada percakapan di bawah ini.

L: Ndeq te kanggo suruq ye berosoq siliq ne ite isiq agama, ndendeq! [nde? to kaygo suru? ya beroso? siliq no ita isi? Agama, ndende?] 'tidak boleh menyuruh dia mencuci piring karena tidak dibenarkan agama, jangan!'

P: Ndeq te kanggo suruq dengan mopo'ang ite. [nde?te ka ngo suru?

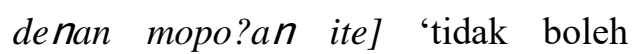
menyuruh orang lain mencucikannya' 
Penggunaan kata ndeq te kanggo 'tidak boleh' dan ndendeq 'jangan' oleh penutur laki-laki, begitu juga penutur perempuan dengan kata ndeq te kanggo di atas, menandakan kedua pihak memiliki kesempatan untuk menyatakan larangannya terhadap sesuatu hal. Pernyataan itu, diujarkan tatkala salah satu pihak atau kelompok merasa sudah terancam atau tertekan dengan pernyataan lawan bicaranya.

Sehingga demikian, suatu tuturan tidak terbebas maksud dan tujuan. Seperti hal tuturan di atas, bahwa teks-teks percakapan tersebut tidak terlepas motif dan pola-pola konteks yang membingkai realita ujaran di balik fakta dan opini yang dipertuturkan para penutur itu sangat benar. Hal ini pun ditegaskan Eggins (2004:86) bahwa teks tidak dapat ditafsirkan sama sekali, kecuali dengan mengacu pada konteks. Sehingga teks dalam bahasa merupakan fenomena sosial yang cenderung digunakan sebagai alat berbuat sesuatu daripada mengetahui sesuatu. Konsep larangan dalam pertuturan Sasak, dengan beberapa konteks percakapan yang telah didata peneliti, sebagian besar dipergunakan untuk menyatakan sesuatu yang tidak dihendaki terjadi.

\subsubsection{Dalam Bentuk Kritikan}

Kritikan merupakan suatu tindakan yang dimaksudkan untuk mengecam, memprotes, dan menegur atas segala sesuatu tidak sesuai dengan pandangan seseorang atau kelompok tertentu. Kritikan biasanya disertai uraian dan pertimbangan baik buruk terhadap sesuatu hal. Kritikan sebagai penanda bahwa seseorang atau kelompok tidak nyaman dengan kondisi tertentu pada percakapan. Suatu tindakan yang dianggap bersinggungan dengan kepentingan pihak lain dapat menimbulkan kecaman dari pihak lain. Kritikan diaktualisasikan dalam berbagai bentuk. Setiap bentuk menunjukan kondisi situasional yang berbeda.
Bentuk kritikan yang diujarkan pada data percakapan bahasa Sasak yang di dapat, sebagian besar berupa sindiran terhadap identitas penutur yang direkonstruksi secara alamiah dan sosial. Adapun bentuk kritikan itu dapat dicermati berikut ini.

P: Asep rokoq mu doang... lelah te beriyaq isiq mu. [asep rook? mu doay lelah to beriya? isi? $\mathrm{mu}$ ] 'asap rokok anda saja, lelah kita bernapas'

L: Mulen ne kanaq nine nih. pernaqperniq ne doang raosang ne. ndaraq ke siq lainan. [mulen na kana' nina nih, perna?-perni? no doay raosay no. ndara? $k \varepsilon$ si? lainan] 'memang benar perempuan ini, pernak-perniknya saja yang dibicarakan'

Kedua bentuk percakapan di atas, yang dituturkan oleh perempuan dan lakilaki, memuat dua hal yang berbeda. Konteks klausa pada penutur perempuan lebih menekankan bentuk identitas sosial laki-laki yang identik dengan rokoq 'rokok'. Istilah rokok sudah tentu ditujukan pada laki-laki. Paradigma masyarakat Sasak sangat tabu memandang rokok untuk perempuan sehingga jika perempuan Sasak merokok di lingkungan sosial dapat menimbulkan stigma yang buruk bagi pelakunya.

Sementara itu, bagi penutur laki-laki, aspek yang dikritik berupa benda alamiah perempuan yang dibentuk oleh keyakinan hakiki terhadap agama. Jilbab merupakan properti perempuan yang sangat kuat melekat pada identitas perempuan. Namun, seiring perkembangan interaksi sosial, istilah jilbab tidak lagi sebagai barang kramat yang dianjurkan agama tetapi dijadikan sebagai gaya (style) dalam berpenampilan.

\subsection{Representasi Gender Melalui Struktur Sintaksis}

Struktur sintaksis merupakan konstruksi klausa atau kalimat dalam tuturan yang dipergunakan untuk merekonstruksi stereotip gender pada setiap tuturan Sasak. 
Pemilihan struktur sintaksis sebagai pengungkap realitas sosial dalam tuturan Sasak sebagai bentuk pengungkapan kritis pada setiap data percakapan. Aspek sintaksis dalam tuturan dapat cermati melalui beberapa hal. Van Dijk (2004) menawarkan beberapa aspek telaah pada konstuksi sintaksi tuturan, yakni penggunaan kosakata atau kata ganti dan bentuk kalimat tuturan. Namun berdasarkan data yang telah dianalisis, sebagian besar diperlihatkan dalam penggunaan pronomina persona atau kata ganti orang. Pemilihan kata ganti bagi Van Dijk (2004) adalah untuk mengamati bagaimana suatu kalimat, klausa, ataupun kata (berupa bentuk dan susunan) yang dipilih membawa makna tertentu. Adapun bentuk penggunaan kata ganti (pronomina persona) oleh penutur perempuan dan lakilaki dapat dicermati pada data berikut ini.

\begin{tabular}{l} 
Penutur Kata Ganti \\
\hline Perempuan \\
\multicolumn{3}{c}{ Kide, Ide, dan } \\
Kamu/-mu* \\
Pengunaan pronomina side dan ide \\
berkonotasi halus, sedangkan penggunaan \\
kata ganti kamu pada situasi yang \\
berkonflik (pertengkaran).
\end{tabular}

Laki-laki Kamu dan $\mathrm{Meq}$

Penggunaan pronomina kamu dan meq berkonotasi kasar dan sangat kasar. Kata ganti ini kerap digunakan oleh laki-laki sebagai bentuk kearogansian dominasinya terhadap kaum perempuan.

*Penggunaan dalam konteks marah dan tidak terkendali dalam interaksi.

Pemilihan kata ganti dalam tuturan Sasak yang didapati sebagian besar direkonstruksi dengan konteks laki-laki yang hierarki sosialnya tinggi dan perempuan berstatus rendah pada masyarakat Sasak. Kata ganti yang dipergunakan para penutur menunjukan ketimpangan gender antarkedua pihak. Laki-laki sangat jarang mempergunakan ragam halus dalam tuturan terhadap pihak perempuan, sebaliknya perempuan yang memosisikan dirinya sebagai sosok yang taat, patuh, dan hormat menunjukan sikap terhadap laki-laki. Hal ini didapat pada ragam halus yang dipergunakan perempuan pada setiap tuturannya dengan laki-laki.

Sehingga demikian, tepat sekali pernyataan Fairclough (2006:63-64; Eriyanto, 2009b:287) ada implikasi dalam tuturan, yakni; seseorang menggunakan bahasa sebagai suatu tindakan terhadap realitas dan adanya hubungan timbal balik antara wacana dan struktur sosial. Sehingga bahasa tuturan yang dipergunakan terlebih dahulu telah dikonstruksi oleh ideologi penutur, kemudian direkonstruksikan oleh masyarakat setempat.

\subsection{Representasi Gender Melalui Pemakaian Metafora}

Pada percakapan, hal-hal yang diungkapkan oleh pelaku dan lawan bicara terkadang diumpamakan dalam wujud bahasa kiasan. Eriyanto (2009:259) mengungkapkan pemakaian kiasan dimaksudkan sebagai ornamen atau bumbu dari suatu berita. Metafora dapat disajikan melalui peribahasa, petuah, atau bahkan ujaran dari agama. Akan tetapi, pemakaian metafora tertentu bisa menjadi petunjuk utama untuk mengerti makna suatu teks.

Menurut Fairclough (dalam 2001:292) bahwa metafora merupkan kunci bagaimana realitas ditampilkan dan dibedakan dengaan orang lain. Metafora bukan hanya persoalan keindahan literer, karena bisa menentukan apakah realitas itu dimaknai dan dikategorikan sebagai positif atau negatif. Militer dapat ditampilkan dengan memberi metafora anak kandung rakyat, anak kandung revolusi, atau pembawa sengsara rakyat. Metafora ini bukan sekadar pemberi identitas atas diri militer. Dengan memberi metafora anak kandung revolusi 
diabstraksikan kepada khalayak bahwa militer baik, mewarisi semangat pejuangan, dan apapun yang dilakukan demi kepentingan rakyat. Sebaliknya, dengan memberikan metafora pembawa sengsara rakyat, militer diabstraksikan sebagai sosok yang oportunis, dan tindakannya merugikan rakyat.

Bentuk metafora yang didapati dan digunakan dalam tuturan berwujudkan penekanan identitas atau pengakuan diri penutur dalam percakapan. Penekanan identitas diujarkan oleh kedua pihak. Keduanya dimungkinkan untuk mengungkapkan metafora penegas jati diri atau identitas di masyarakat. Sehingga keadaan ini telah didapati dalam setiap percakapan mempergunakan cara ini untuk menyatakan kesuperioritasannya. Adapun data percakapan Sasak yang didapati yang memuat tentang penegasan identitas diri melalui metafora sebagai beikut.

P: Jari ite doang penunggu pawon leq bale. ite ngeme, kelaq raun, ngerosoq. [jari ito doay panuygu pawon le? bale, ite yame kela? raun yoroso?] 'jadi kami saja yang menjaga dapur di rumah. Saya masak nasi, masak lauk, dan mencuci piring'

L: Wajar so kanaq mame... inget, pituq banding sekeq mame dait nine no. [wajar so kana? mama. Inget, pitu? bandin seke? mama kance nine no] wajar kalau laki-laki seperti itu. Ingat tujuh berbanding satu, laki-laki dengan perempuan itu.'

Penggunaan klausa 'jadi kami saja penunggu dapur di rumah' oleh perempuan merupakan bentuk pengungkapan jati dirinya yang selalu dikaitkan dengan kondisi sosial yang menempatkan dirinya yang hanya pantas pada aspek domestik. Sedangkan pihak laki-laki dengan tuturan 'ingat tujuh banding satu laki-laki dengan perempuan' yang menandakan betapa berkuasanya pihak laki-laki Sasak dalam masyarakatnya.

Penggunaan metafora seperti halnya di atas, secara langsung telah diperlihatkan jarak sosial (gap) yang membatasi akses sosial antarkedua pihak. Perempuan diidentik dengan dapur rumah tangga dan laki-laki yang jumlahnya lebih sedikit dibanding perempuan (menurut keyakinan agama) semakin meregangkan kesetaraan keduanya dalam tuturan.

\section{Penutup}

Berdasarkan hasil dan pembahasan data penelitian di atas, dapat disimpulkan bahwa peristiwa tutur dalam bahasa Sasak cukup sarat dengan ideologi terselubung yang memuat ragam motif dan pola yang menstereotipkan perempuan dalam tuturan Sasak. Perempuan hanya sosok yang dianggap pantas pada sektor domestik, sedangkan sektor publik adalah ranah yang hanya diduduki oleh pihak laki-laki.

Bentuk penggolongan pola percakapan dalam tuturan Sasak, secara jelas menunjukan ketimpangan gender. Ketidakadilan gender itu, ditunjukan melalui pemilihan kosakata, kendali interaksional, struktur sintaksis, dan pemakaian metafora secara tidak langsung telah menunjukan ragam stigma pemikiran yang menekan atau ditekan oleh sesuatu kekuatan dominan dalam masyarakat.

Tidak bisa disangkal, kondisi percakapan seperti ini tidak menutup kemungkinan dapat menimbulkan konflik horizontal dalam pergaulan masyarakat berbasis gender. Masyarakat Sasak menempatkan pihak laki-laki sebagai sosok yang lebih unggul dari pihak perempuan, sehingga dalam pergaulan keseharian perempuan Sasak kerap menjadi objek (penderita) dari kearogansian laki-laki, seperti: membudayanya kawin cerai, makin banyaknya anak tanpa ayah atau ibu, dan belum lagi kasus KDRT yang kerap 
... Sebuah Kajian Wacana Kritis (Irma Setiawan)

menimpa kaum perempuan dalam kehidupan bermasyarakat. Tanggap konflik melalui sikap kritis terhadap percakapan masyarakat Sasak seperti ini diharapkan sebagai langkah awal mengenal dan memahami benih-benih konflik yang dapat memicu masalah yang lebih besar. Untuk itu, pemerintah semestinya acuh terhadap persoalan gender sebagai isu yang serius dan akut baik di tingkat daerah maupun nasional.

\section{Daftar Pustaka}

Darma, Yoce Aliah. (2009). Analisis Wacana Kritis. Bandung: CV KRAMA WIDYA.

Eggins, Suzanne. (2004). An Introducing to Systemic Functional Linguistics. London: Continuum.

Eriyanto. (2009). Analisis Wacana: Pengantar Analisis Teks Media. Yogyakarta: LKiS.

Fairclough, Norman. (1989). Language and Power. London: Longman.

(1998). Critical Discourse Analysis. London: Longman. . (2006). Language and Social Change. Cambridge: Polity Press.

Jorgensen, Marianne W. dan Phillips Louise J. (2007). Analisis Wacana: Metode dan Teori. (Abdul Syukur Ibrahim, penerjemah). Yogyakarta: Pustaka Pelajar.

Kadarusman. (2005). Agama, Relasi Gender, dan Feminisme. Yogyakarta: Kreasi Wacana.

Mahsun. (2007). Edisi Revisi: Metode Penelitian Bahasa: Tahapan Strategi, Metode, dan Tekniknya. Jakarta: PT Raja Grafindo Persada.

Nugroho, Rian. (2008). Gender dan Administrasi Publik: Studi Tentang
Kualitas Kesetaraan Gender dalam Administrasi Publik Indonesia Pascareformasi 1998-2002. Yogyakarta: Pustaka Pelajar.

Santoso, Anang. (2009). Bahasa Perempuan: Sebuah Ideologi Perjuangan. Jakarta: Bumi Aksara.

Tim Penyusun. (2012). Stagnansi Sistem Hukum: Menggantung Asa Perempuan Korban: Catatan Kekerasan Terhadap Perempuan 2011. Jakarta: Komnas Anti Kekerasan terhadap Perempuan.

Van Dijk, Teun A. (2004). Ideology and Discourse. Barcelona: Ariel. 